\title{
Vitamin D concentrations and biological biomarkers of lactating mares and foals in the dry season
}

\author{
Mychelle Bruna da Silva Barros', Monica Miranda Hunka', Luzilene Araujo de Souza', Carolina Jones Ferreira Lima da Silva', Clarisse \\ Simões Coelho², Helena Emília C. C. C. Manso' and Helio Cordeiro Manso Filho'
}

1 Equine Research Nucleus, Department of Animal Science, Federal Rural University of Pernambuco, Recife, Pernambuco, Brazil

2 Federal University of Bahia, Salvador, Bahia, Brazil.

\begin{abstract}
Summary: During the lactation phase, there is an intense mobilization of blood biomarkers in the tissues for milk production by mares, while the foals face challenges and metabolic adaptations essential for their development. To determine variations in the haematological, lipid, protein, and vitamin D (VIT-D) profiles between lactating mares and their foals, blood samples were obtained during the entire lactation period under a semi regime in the Caatinga. Animals were maintained on Buffel grass, mineralized salt, and a mixture of mesquite bran and corn roll, and water was provided ad libitum. In addition, the foals had free access to a creeper-feeder with commercial concentrate. Concentrations of total cholesterol, high- and low-density lipoproteins, triglycerides, VIT-D, erythrocytes, haemoglobin, total plasma protein and albumin, and haematocrit and leukocytometric levels were determined in serum blood samples. No body mass changes were observed in the lactating mares; however, it increased in the foals, the values ranged from $56 \mathrm{~kg}$ to $165 \mathrm{~kg}$, in the end of the study. Alterations in lipid biomarkers compatible with the physiological phase were observed. The concentration of lipids in the blood of the foals was higher than that in the mares. Thus, the alterations observed were compatible with the metabolic modifications during the lactation phase in mares and their foals. The concentrations of VIT-D of mares and foals were low; it is important to note during the standardization of these values for horses raised under tropical conditions and exposed to high solar incidence. Therefore, these findings may be useful for the evaluation of animals in tropical climates under conditions of high solar incidence.
\end{abstract}

Keywords: horse, lipid metabolism, equine nutrition, vitamin D, biological marker

Citation: Bruna da Silva Barros M., Hunka M. M., Araujo de Souza L., Jones Ferreira Lima da Silva C., Simões Coelho C., Manso H. E. C. C. C., Cordeiro Manso Filho H. (2019) Vitamin D concentrations and biological biomarkers of lactating mares and foals in the dry season. Pferdeheilkunde 34, 344-350; DOI 10.21836/PEM20190406

Correspondence: Dr. Mychelle Bruna da Silva Barros, Equina Research Nucleus, Department of Animal Science, Federal Rural University of Pernambuco, Av. Dom Manuel de Medeiros, 52171-030 Recife, Pernambuco, Brazil; mychellebarros@gmail.com

Received: December 21, 2018 | Accepted after revision: June 11, 2019

\section{Introduction}

The lactation phase is a challenge for both the lactating mare and its foal. They experience important changes in metabolism basal, concentrations of different blood biomarkers, and body composition, and the metabolism in mares and foals become largely catabolic and anabolic, respectively. In the mares, lactation lasts about 180 days and may vary depending on herd management, and peak milk production occurs between the 2 nd and $3 r d$ month of lactation, with a subsequent rapid decline (Doureau et al. 1991 b).

During lactation, blood and hormonal changes that may be affected by the availability of precursors lipids occur in mares. Cholesterol (COLE) is necessary for the synthesis of gonadal and cortico-adrenal hormones, bile salts, and vitamin D (VIT-D), and participates in the composition of tissues and secretions, such as milk (Coppo 2001). The concentration of COLE may vary according to physiological conditions, lactation phase, and diet provided to the animal. At the end of a pregnancy, there is a tendency for the concentration of COLE to reduce, reaching minimum values during parturition due to the needs of the foetus and, to a lesser extent, for the synthesis of sexual and adrenals hormones, as described in cattle by Guedon et al. (1999). Postpartum, its concentrations are normalized - an indicator of the ability to mobilize the stocks of adipose tissue and a large proportion of triglycerides (TRIG), transported by lipoproteins, for the synthesis of milk.

Vitamin D is a steroid, and comes from the existing COLE in the plasmatic membrane of the skin (7-dehydrocholesterol), which is cleaved by the ultraviolet light of the sun to form pre-vitamin D3. Its transport in the tissues is linked to plasma proteins and it is transformed by the liver and kidneys before becoming biologically active (25-(OH) D3); most of it is stored in the adipose tissue, its main reservoir (Boullion 2001). In equine milk, VIT-D concentrations are low, equivalent to $0.0032 \mathrm{mg} / \mathrm{kg}$ (Csapó et al. 1995), and sun exposure is its main source. Among its functions are the regulation and maintenance of plasma levels of calcium (Ca) and phosphorus (P), stimulation of gastrointestinal absorption and renal resorption, and modulation of osteoblastic activity and bone resorption (Champe et al. 2006). In horses, the metabolism and functions of VIT-D seem to differ in many aspects of other animal species (Boarse and Toverud 1996; Breidenbach et al.1998), in addition to seasonal and circadian variations in their serum concentrations. 
Blood components, like proteic and lipidic profile and hematological values are important for assessing the condition of mares during the lactation phase, reflecting the metabolic rates (Milinkovic-Tur 2005) and presenting a dynamism between metabolism and this physiological challenge (Silva 2018). It is also an important tool used for monitoring developing animals.

The purpose of this study was to determine if lactation modifies lipid, haematological, proteomic, and VIT-D biomarkers in mares and their foals kept in pasture.

\section{Material and methods}

The experiment was carried out in the city of Gravatá-PE $108^{\circ}$ $\left.12^{\prime} 04^{\prime \prime} \mathrm{S} ; 35^{\circ} 33^{\prime} 53^{\prime \prime} \mathrm{W}\right)$, a transitional region with a deciduous Caatinga forest and annual precipitation between 600 and $900 \mathrm{~mm}$ (Da Silva et al. 2018), during the dry season, between January and June, 2017. For the experimental group, seven healthy, lactating females, from eight to fourteen years old, of the Mangalarga Marchador (MM) breed with a body condition score between 4 and 6 (Henneke et al. 1983), and about $420 \mathrm{~kg}$ at parturition, and their respective foals were used. The control group consisted of nine MM breed fillies, healthy, nulliparous, and under the same management plan as the breeding mares, body condition score between 4 and 6 , and $336 \mathrm{~kg}$ of BW. All animals were randomly selected from a herd of 65 .

The mares were maintained in a semi-intensive-breeding regime in pickets of approximately 10 hectares, with a pasture of Buffel grass (Cenchrus ciliaris), mineralized salt (CoEqui Plus ${ }^{\circledR}$-Tortuga, Brazil), and water provided ad libitum. They were fed $2.0 \mathrm{~kg}$ of a mixture of mesquite bran and corn roll (gross energy: $4.251 \mathrm{kcal} / \mathrm{kg}$; ether extract: $1.86 \%$; crude protein: $9.43 \%$; acid detergent fibre: $25.75 \%$; mineral matter: $2.33 \%)$. The foals had free access to a creep-feeder with a commercial concentrate (B-LINE 100 Royal-Horse ${ }^{\circledR}-\mathrm{Neo}$ via, Brazil (gross energy: $2.920 \mathrm{kcal} / \mathrm{kg}$; ether extract: $3.5 \%$; crude protein: 16\%; acid detergent fibre: 17\%; mineral matter: $15 \%)$ ) from birth. All the mares produced their colostrum and milk regularly.

\section{Experimental phase}

Blood samples were performed, via jugular venopuncture, with a negative pressure system in tubes without anticoagulant and in tubes with EDTA anticoagulant. Subsequently the blood was centrifuged to isolate the serum and plasma, which were then stored at $-18^{\circ}$ until processing. The collections were made monthly, from parturition to weaning, both in the mares and foals. For the fillies in the control group, the collections were performed in alternate months. Prior to collection, animals were fasted for a minimum of 8 hours of concentrate, and the blood samples were obtained between January and June, during the dry season. The body weight was obtained with a weighing scale.

\section{Statistical analysis}

The comparisons between each group over time were evalvated using a one-way ANOVA (time/experimental phase), and a Tukey's post-hoc test. A significance level of $5 \%$ was considered for all statistical assessments, and the results were expressed as mean \pm average standard error. The Software SigmaPlot 13.0 (Systat software Ins., San Jose-CA, USA) was used for all analyses.

\section{Results}

No changes in the body mass of the mares during the lactation period $(p<0.05)$ were observed. In contrast, there was an increase in the body mass in the first five months of the foals' lives $(p<0.05)$ (Table 1).

In the mares (Table 2), there was no significant difference between the concentrations of COLE, HDL, and LDL between groups $(p<0.05)$. However, these increased from birth to weaning in the foals (Table 2). No changes in triglycerides (TRIG) were observed in the evaluated phases of all experimental groups $(p<0.05)$ (Table 2).

There were significant differences $(p<0.05)$ in the VIT-D concentrations of the lactating mares; it decreased in the mares and increased in the foals over time (Table 2).

The number of erythrocytes in the different groups did not vary from the control $(p<0.05)$ in the mares and their foals (Table 3). However, the haematocrit levels of the mares and foals decreased $(p<0.05)$ over time. Similar results were observed for haemoglobin values, with the highest values found in mares after parturition $(p<0.05)$ (Table 3). The leukocyte count of the mares did not differ from that of the control, however, it increased over time in the foals $(p<0.05)$ (Table 3$)$.

The total protein plasm (TPP) concentration of mares, foals, and the control group was high, but not statistically different (Table 3) $(p<0.05)$. The mean ALB levels observed in the

Table 1 Body mass $(\mathrm{kg})$ of lactating mares and their Mangalarga Marchador foals, during the lactation period.

\begin{tabular}{|c|c|c|c|c|c|c|}
\hline \multirow{2}{*}{ Group } & \multicolumn{6}{|c|}{ Experimental phase } \\
\hline & Birth & 1st month & 2nd month & 3rd month & 4th month & 5th month \\
\hline Mares & $420.00 \pm 23.17$ & $402.00 \pm 16.14$ & $386.00 \pm 14.60$ & $397.43 \pm 15.60$ & $390.71 \pm 11.45$ & $389.85 \pm 10.30$ \\
\hline Foals & $56.50 \pm 7.20 C$ & $74.57 \pm 9.50 C$ & $109.86 \pm 5.63 \mathrm{AB}$ & $137.71 \pm 6.80 \mathrm{~A}$ & $154.71 \pm 7.11 \mathrm{~A}$ & $164.85 \pm 7.02 \mathrm{~A}$ \\
\hline Control & $336.33 \pm 17.90$ & --.----- & ----------- & $335.00 \pm 9.07$ & 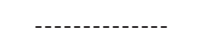 & $338.00 \pm 11.00$ \\
\hline
\end{tabular}

Different letters on the same line indicate that $p<0.05$ by Tukey Test 
three study groups (Table 3) remained within the expected limits.

\section{Discussion}

The mobilization of body reserves during the lactation and growth of mares and foals, respectively, is necessary to meet their energy and protein requirements. There was no significant reduction in the body mass of the mares during the lactation period (Table 1), even with a decrease in body mass of approximately $31 \mathrm{~kg}$, about $7 \%$. In mares fed with concentrate meeting the requirements of the NCR (2007), it was shown that they do not lose body or fat mass, only mass-free of fat (Silva et al. 2018). However, in the present experiment the body composition was not determined, which could make the possible body adaptations of the mares to the lactation period clearer. The absence of body mass differences may be due to supplementation with a mixture of mesquite and corn roll along with the Buffel grass freely available in the pastures. In foals there was an increase in body mass during lactation, as expected. Similarly, Saastamoinen (1996) found that the growth of foals during the first year was fast, reaching $65 \%$ of their definitive weight at 12 months. During the five months evaluated, the percentage of body mass gained was from $94 \%$, similar to findings by Santos et al. (2005). However, there are reports of lower gains, approximately $0,71 \mathrm{~kg} / \mathrm{day}$ (Santos et al. 2000), in systems of extensive breeding, where foals were maintained on pasture with no supplementary feeding. This may have influenced the results as supplementation is important to meet the nutritional requirements of the foal because of the reduction in milk constituents during the lactation period (Doureau et al. 1991b).

The concentration of COLE of the evaluated mares remained within the levels found by Ferreira et al. 2016, who studied with mares in during lactation. This may be due to their ability to mobilize the stocks of fatty tissue for milk synthesis. This occurs at the tissue level and milk fat represents $1-1.5 \%$ of its constitution (Gibbs et al. 1982); there is constant production until levels reach their peak in the 2 nd month of lactation,

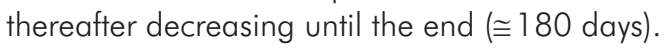

According to Howard et al. (2007), cholesterol levels are high from birth with maximum values observed at $16-48 \mathrm{~h}$, in foals of the Brazilian equestrian race. This is due to the demands of this lipid on the liver during the development of the new born, steroidogenesis of tissues, and metabolization of brown adipose tissue (Beitz 1996). The concentrations of COLE, HDL, and LDL in the foals of this study corroborate the findings of Ropp et al. (2003) and Howard et al. (2007). Elevated LDL are associated with an increased digestive ab-

Table 2 Serum concentrations of total cholesterol, HDL, LDL, triglycerides and vitamin D (25-OH) of lactating mares and their Mangalarga Marchador foals, during the lactation period.

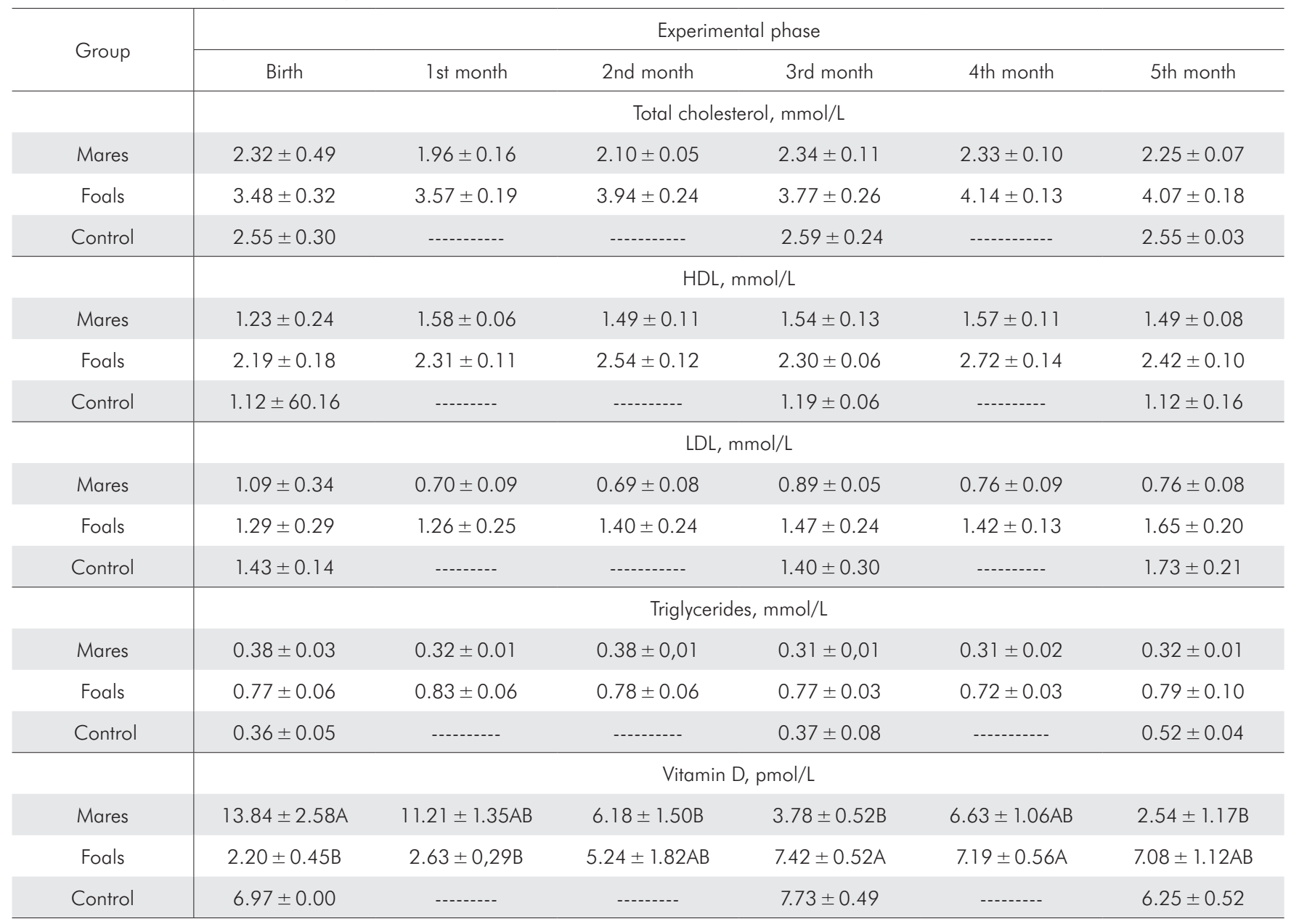

Different letters on the same line indicate that $p<0.05$ by Tukey Test 
sorption of COLE for the formation of bile salts in animals with fat-rich diets (Diniz et al. 2014). In addition, because of the introduction of concentrated feeding in the creep-feeder system, elevated LDL may represent a response to metabolic adaptations occurring during the neonatal period, ensuring a better utilization of energy resources. Nevertheless, Howard et al. (2007) found that in the first months of life, plasma cholesterol levels are higher than those in one or two year-old animals (Asadi et al. 2006).

The determination of TRIG concentrations of mares becomes important, as in conjunction with COLE and AGL, they directly affect the availability and mobilization of fatty tissue fats, representing the conditions of the animal and possible adaptations to the use of fats and/or other foods under different conditions (Oldruitenborgh Oosterbaan et al. 2002, Mélo et al. 2012). In this study, no significant variations in TRIG concentrations of mares were observed, and even after their mobilization for milk production, concentrations remained with- in expected levels for healthy horses (Santiago et al. 2014, Magalhães et al. 2017).

In the foals, we found elevated TRIG concentrations from birth to weaning, maintained within physiologically levels during the first weeks of life. This slight hypertriglyceridemia in foals may be a manifestation of hepatic immaturity at birth (Schmid and McDonagh 1978), or simply a result of the milk consumption, as TRIG are the most abundant lipids in milk (Beitz 1996). Amaral et al. (2017) measured the adiposity between foals created during extensive and intensive regimens, and observed that the foals of the extensive system showed greater lipid mobilization, characterized by higher levels of TRIG and $A G L$, similar to findings of this study.

Pozza et al. (2014) conducted a study with horses and foals of English Thoroughbreds in Thailand and the United States, where the dosages of VIT-D, 25- $(\mathrm{OH}) \mathrm{D} 3$, obtained by serum blood samples, given were $14.4-30.5 \mathrm{ng} / \mathrm{ml}$ and 14.3

Table 3 Hematimetria, leukocyte count and serum concentrations of total plasma protein and albumin of lactating mares and their Mangalarga Marchador foals, during the lactation period.

\begin{tabular}{|c|c|c|c|c|c|c|}
\hline \multirow{2}{*}{ Group } & \multicolumn{6}{|c|}{ Experimental phase } \\
\hline & Birth & 1st month & 2nd month & 3rd month & 4th month & 5th month \\
\hline & \multicolumn{6}{|c|}{ Erythrocytes, $\times 10^{6} / \mathrm{mL}^{3}$} \\
\hline Mares & $7,89 \pm 0,30$ & $6,75 \pm 0,38$ & $6,13 \pm 0,48$ & $6,36 \pm 0,34$ & $6,20 \pm 0,49$ & $5,97 \pm 0,32$ \\
\hline Foals & $10,46 \pm 0,51$ & $10,73 \pm 0,22$ & $11,23 \pm 0,33$ & $9,55 \pm 1,35$ & $11,25 \pm 0,23$ & $9,35 \pm 0,61$ \\
\hline \multirow[t]{2}{*}{ Control } & $8,87 \pm 0,39$ & --------- & --------- & $8,18 \pm 0,31$ & --------- & $8,93 \pm 0,27$ \\
\hline & \multicolumn{6}{|c|}{ Hemoglobin, g/dL } \\
\hline Mares & $12,66 \pm 0,63 \mathrm{~A}$ & $10,93 \pm 0,52 \mathrm{AB}$ & $10,18 \pm 0,68 \mathrm{AB}$ & $10,21 \pm 0,50 \mathrm{AB}$ & $9,91 \pm 0,63 \mathrm{AB}$ & $8,93 \pm 0,56 \mathrm{~B}$ \\
\hline Foals & $12,95 \pm 0,42 \mathrm{AB}$ & $12,63 \pm 0, A B$ & $12,97 \pm 0,38 \mathrm{~A}$ & $12,47 \pm 0,21 \mathrm{AB}$ & $13,04 \pm 0,42 \mathrm{~A}$ & $11,00 \pm 0,65 B$ \\
\hline \multirow[t]{2}{*}{ Control } & $11,96 \pm 0,72$ & $-\cdots---$ & --.----- & $11,16 \pm 0,37$ & $-\cdots----$ & $12,43 \pm 0,24$ \\
\hline & \multicolumn{6}{|c|}{ Hematocrit, $\%$} \\
\hline Mares & $37,46 \pm 1,82 \mathrm{~A}$ & $31,81 \pm 1,49 \mathrm{AB}$ & $29,41 \pm 2,00 \mathrm{AB}$ & $29,70 \pm 1,46 \mathrm{AB}$ & $28,94 \pm 1,97 \mathrm{AB}$ & $27,33 \pm 0,94 \mathrm{~B}$ \\
\hline Foals & $40,57 \pm 1,81 \mathrm{AB}$ & $40,30 \pm 1,00 A B$ & $41,63 \pm 1,26 \mathrm{~A}$ & $40,21 \pm 0,75 \mathrm{AB}$ & $41,60 \pm 1,37 \mathrm{~A}$ & $33,71 \pm 2,11 \mathrm{~B}$ \\
\hline \multirow[t]{2}{*}{ Control } & $36,83 \pm 1,61$ & -------- & --------- & $34,06 \pm 1,18$ & ------- & $36,63 \pm 0,14$ \\
\hline & \multicolumn{6}{|c|}{ Leukocytes, / $\mu \mathrm{L}$} \\
\hline Mares & $9,80 \pm 0,89$ & $11,33 \pm 0,97$ & $11,68 \pm 1,16$ & $10,84 \pm 0,74$ & $9,85 \pm 0,61$ & $10,37 \pm 0,80$ \\
\hline Foals & $11,70 \pm 1,36 \mathrm{~B}$ & $12,45 \pm 0,22 B$ & $13,68 \pm 0,91 \mathrm{AB}$ & $15,54 \pm 1,00 \mathrm{AB}$ & $15,74 \pm 0,90 \mathrm{AB}$ & $16,87 \pm 0,92 \mathrm{~A}$ \\
\hline \multirow[t]{2}{*}{ Control } & $12,06 \pm 1,01$ & --.--.--- & -..--..-. & $11,83 \pm 0,28$ & --.---.-- & $12,56 \pm 1,67$ \\
\hline & \multicolumn{6}{|c|}{ Plasma proteins, $\mathrm{g} / \mathrm{L}$} \\
\hline Mares & $0.11 \pm 0.01$ & $0.12 \pm 0.01$ & $0.12 \pm 0.01$ & $0.12 \pm 0.01$ & $0.12 \pm 0.01$ & $0.11 \pm 0.01$ \\
\hline Foals & $0.09 \pm 0.01$ & $0.11 \pm 0.01$ & $0.12 \pm 0.01$ & $0.13 \pm 0.01$ & $0.13 \pm 0.01$ & $0.13 \pm 0.01$ \\
\hline \multirow[t]{2}{*}{ Control } & $0.10 \pm 0.01$ & -------- & --.---.-- & $0.12 \pm 0.01$ & ------- & $0.12 \pm 0.01$ \\
\hline & \multicolumn{6}{|c|}{ Albumin, g/L } \\
\hline Mares & $0.03 \pm 0.01$ & $0.03 \pm 0.01$ & $0.03 \pm 0.01$ & $0.03 \pm 0.01$ & $0.03 \pm 0.01$ & $0.03 \pm 0.01$ \\
\hline Foals & $0.03 \pm 0.01$ & $0.03 \pm 0.01$ & $0.03 \pm 0.01$ & $0.03 \pm 0.01$ & $0.03 \pm 0.01$ & $0.03 \pm 0.01$ \\
\hline Control & $0.03 \pm 0.01$ & 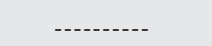 & - - & $0.03 \pm 0.01$ & $-\cdots---$ & $0.03 \pm 0.01$ \\
\hline
\end{tabular}

Different letters on the same line indicate that $\mathrm{p}<0.05$ by Tukey Test, Reference values for Erythrocytes: 7.80/13.20 and 7,00/13.00 × 106/ml, Hemoglobin: 10.50/17.20 and 10.00/18.00 g/dl, Hematocrit: 29/44 and 32/48\%, Leucocytes 5.30/14.60 and 7.00/14.00/ $\mu \mathrm{l}$, for foals and mares, respectively 
$37.2 \mathrm{ng} / \mathrm{ml}$, respectively, with no statistical difference between the two groups. The foals had lower VIT-D concentrations than the adult horses, with values of $9.3-22 \mathrm{ng} / \mathrm{ml}$ in Thailand, and $9.5-19.2 \mathrm{ng} / \mathrm{ml}$ in the United States, with no significant difference between the sites studied. These findings are similar to that of other studies (Breidenbach et al. 1998, Piccione et al. 2008). However, these studies found differences between age groups of horses in contrast to findings of our study, where VIT-D concentrations of mares and foals were inversely related.

The low VIT D concentrations observed in foals may be related to lower serum concentrations of DPB (vitamin D binding protein), essential in the metabolism of this vitamin, in neonates and foals compared to the mares (Madej et al. 2009). Seasonal differences are also reported in horses, with higher values in summer than in winter months, as well as in humans, where people living near the Equator Line have higher concentrations of 25- $(\mathrm{OH})$ D3 due to exposure to longer periods of sunlight (Hagenau et al. 2009).

Therefore, due to the climatic conditions and the geographic location of the study area (Gravatá, Pernambuco, Brazil), exposure to sunlight and proximity to the equator line, were not sufficient to raise the levels of VIT-D. Moreover, the decline in VIT-D concentrations in the mares, corresponds to the same period in which authors reported seasonal influences on reproductive activities (Manso Filho et al. 2000). Unfortunately, there are no studies suggesting the requirements of VIT-D under different management conditions (Hymoller and Jensen 2015), or of pre-vitamin D2 in pastures to determine an adequate level for its supplementation in concentrated diets.

The haematimetric parameters of the mares reflect haemoglobin and haematocrit values lower than those found by Ferreira et al. (2016) in MM-breed animals with age ranging from 5 to 15 years, receiving Elephant Grass (Pennissetum purpureum) and comercial concentrate, in an intensive management system. This may be related to increases in the plasmatic volume observed during the lactation period, without represent pathological conditions (Hunka et al. 2015). In this phase, hormonal variations still occur, with the activation of the renin-angiotensin-aldosterone system promoting an increase in the body's fluid content (Cheung and Lafayette 2013) increased renal reabsorption of sodium and water retention (Bazzano et al. 2014b), which leads to an expansion of the plasmatic volume, a reduction in the amount of circulating erythrocytes, and an increase in the synthesis of TPP (Satué and Moutesinos 2013). Its is known that a poor ingestion of water, and/or dehydration conditions could change the plasma volume. Decreases in haematocrit and haemoglobin levels in lactating mares were also found by Bazzano et al. (2014b) and Hunka et al. (2015). In relation to red blood cells, the values obtained were within the limits set by Koteba (1990) and lower than that observed by Ferreira et al. (2016). This is probably because of the progressive and gradual haemodilution due to plasma expansion, and an anaemia may be installed low-intensity regenerative at this stage (Silva 2018). Nevertheless, according to Silva (2018), during the transitional period, Mangalarga Marchador mares maintained in pasture have low erythrocyte counts and haematocrit levels, suggesting that metabolic variations are due to adap- tive processes; this is corroborated by findings of this study. In foals, the haematocrit levels and erythrocytes concentration, despite fluctuations during the period evaluated $(p<0.05)$, remained within the reference values cited by Koteba (1990) and Kaneko (2008) for each evaluated phase, with no significant difference between each phase (Koteba 1990).

The TPP concentrations of mares, foals, and individuals in the control group $(6.0-8.0 \mathrm{mg} / \mathrm{dl})$ were higher than that recorded by Caviglia et al. (2000). Variations in TPP are indicative of loss or sequestration of bodily fluids to other parts of the body and may also be an indicator of the level of external stimulation experienced by the animal during blood collection (McKeever et al. 2006) and the expansion of blood volume in lactating mares (Jain 1986). In the equine neonate, TPP concentration is related to the transfer of passive immunity, and its elevation is linked to an increase in serum globulins after intestinal absorption of colostrum macromolecules (Lassen 2007). It's important to explain that the control group was evaluated in the beginning, in the middle and in the end of the study, because we had in mind that this group wasn't submitted to any treatment, therefore, no changes were expected throughout the study.

\section{Conclusion}

The concentration of lipids in the blood of the foals was higher than that in the mares, most of the time, and fell within the established values for the age range studied and the related metabolic adaptations. The concentrations of VIT-D of mares and foals were low; this is important to note during the standardization of these values for horses raised under tropical conditions and exposed to high solar incidence. The blood and protein parameters of the mares exhibited dynamic variations due to the metabolic changes experienced during the lactation phase, whereas the values of the foals remained within the standard physiological amplitude.

\section{Conflict of interest}

None of the authors have any conflict of interests.

\section{Animal Welfare Statement}

The UFRPE-CEUA Ethics and Animal Welfare commission authorized this research by protocol No. 77/2016.

\section{References}

Amaral L. A., Marchiori M., Mores B. S., Finger I., Santos R. S., Nogueira C. E. W. (2017) Relação entre adiposidade, perfil energético, proteínas inflamatórias e lesões osteoarticulares em equinos jovens sob diferentes sistemas de criação. Pesq. Vet. Brasil. 37,1 15-120; DOI 10.1590/s0100-736x2017000200004

Asadi F., Mohri M., Adibmoradi M., Pourkabir M. (2006) Serum lipid and lipoprotein paramaters of Turkman horses. Veterinary Clinical Pathology, v. 35, n. 3, 332-334

Beitz D. Metabolismo lipídico. In: Reece W. O. (1996) Fisiologia dos animais domésticos. Rio de Janeiro: Guanabara-Koogan; DOI 10.1111/j.1939-165X.2006.tb00142.x 
Bazzano M., Giannetto C., Fazio F., Rizzo M., Giudice E., Piccione G. (2014b) Physiological adjustments of haematological profile during the last trimester of pregnancy and the early post partum period in mares. Anim. Reprod. Sci. 149, 199-203; DOI 10.1016/i.anireprosci.2014.07.005

Boass A., Toverud S. U. (1996) Duodenal active calcium transport in female rats increases with serum calcitriol concentrations, but reaches a plateau far below maximal calcitriol levels. J. Bone Min. Res. 11, 1640-1645; DOI 10.1002/jbmr.5650111107

Bouillon R. (2001) Vitamin D: from photosynthesis, metabolism, and action to clinical applications. In Endocrinology. Edited by: DeGroot L. J., Jameson J. L. Philadelphia: W. B. Saunders, 10091028

Breidenbach A., Schlumbohm C., Harmeyer J. (1998) Peculiarities of vitamin $D$ and of the calcium and phosphate homeostatic system in horses. Vet. Res. 29, 173-186

Caviglia J. F. E., Perrone G. M., Chiappe A., Taffarel C., González G. (2000) Evaluácion de parâmetros hematológicos e bioquímicos pos ejercicio em caballos de pato. Rev. Med. Vet. Buen. Air. 8, 75-78

Champe P. C., Harvey R. A., Ferrier D. R. (2006) Bioquímica ilustrada. Porto Alegre: Artmed, 533

Cheung K. C., Lafayette R. A. (2013) Renal physiology of pregnancy. Adv. Chron. Kind. Dis. 20, 209-214

Csapó J., Stefler J., Martin T. G., Makray S., Csapó-Kiss Z. (1995) Composition of Mares' Colostrum and Milk. Fat Content, Fatty Acid Composition and Vitamin Content. Int. Dairy J. 5, 393-402; DOI 10.1016/0958-6946(94)00008-D

Coppo J. A. (2001) Fisiología Comparada del Medio Interno, Ed. Dunken, Buenos Aires

Da Silva Y. J. A. B, Do Nascimento C. W. A., Biondi C. M., Van Straten P., Da Silva Y. J. A. B. (2018) Rare earth element geochemistry during weathering of $S$-type granites from dry to humid climates of Brazil. J. Plant Nutr. Soil Sci. 000, 1-16; DOI 10.1002/jpln.201700440

Diniz A. I. A., Almeida T. L. A. C., Barbosa B. L., Lira V. L., Manso H. E. C. C. C., Manso Filho H. C. (2014) Biomarcadores lipídicos no plasma de equinos suplementados com uma mistura de óleos. Ciênc. Vet. Tróp. Recife-PE, 17, 30

Doreau M., Boulot S., Bauchart D., Barlet, J.-P., Martin-Rosset W. (1991b) Voluntary intake, milk production and plasma metabolites in nursing mares fed two different diets. Nutrition 122, 992-999; DOI 10.1093/in/122.4.992

Ferreira L. M. C., Hunka M. M., da Silva E. R. R., Melo S. K. M., de Melo A. C. C., Trindade K. L. G., Oliveira V. T. B. M., Manso H. E. C. C. C., Manso Filho H. C. (2017) Hematological and biochemical values in Brazilian four-beat gaited horses. Comp. Clin. Pathol. 26, 321-327; DOI 10.1007/s00580-016-2364-4

Guedon L., Saumande J., Desbals B. (1999) Relationships between calf birth weight, prepartum concentrations of plasma energy metabolites and resumption of ovulation postpartum in limousine suckled beef cows. Theriogenology 52, 779-789; DOI 10.1016/ S0093-691X(99)00171-5

Gibbs P. G., Potter G. D., Blake R. W., McMullan W. C. (1982) Milk production of Quarter horse during 150 days of lactation. J. Anim. Sci. 54, 497-450; DOI 10.2527/jas1982.543496x

Hagenau T., Vest R., Gissel T. N., Poulsen C. S., Erlandsen M., Mosekilde L., Vestgaard P. (2009) Global vitamin D levels in relation to age, gender, skin pigmentation and latitude: an ecologic meta-regression analysis. Osteop. Int. 20, 133-40; DOI 10.1007/ s00198-008-0626-y

Henneke D. R., Potter G. D., Kreider J. L., Yeates B. F. (1983) Relationship between condition score, physical measurement, and body fat percentage in mares. Equine Vet. J. 15, 371-272; DOI 10.1111/j.2042-3306.1983.tb01826.x
Howard D. L., Benesi F. J., Gacek F., Coelho C. S., Fernandes W. R. (2007) Determinações plasmáticas de glicose, colesterol e triglicérides em potras sadias, da raça Brasileiro de Hipismo. Braz. J. Vet. Res. Anim. Sci. 44, 454-458

Hymoller L., Jensen S. K. (2015) We know next to nothing about Vitamin D in horses! J. Equine Vet. Sci. 35, 785-792; DOl 10.1016/i. jevs.2015.06.010

Hunka, M. M., Silva, E. R. R., Vaz, S. G., Ferreira, L. M. C., Manso, H. E. C. C. C., Manso Filho, H. C. (2015) Avaliação Hematológica de éguas em lactação mantidas a pasto. Rev. Ciênc. Vet. Tróp. $18,323-325$

Jain N. C. (1986) Schalm's Veterinary Hematology. 4th ed. Lea and Febiger, 600. Washington square, Philadelphia, USA

Kaneko J. J., Harvey J. W., Bruss M. L. (2008) Clinical biochemistry of domestic animals. 6th Ed. San Diego: Academic Press, 916

Koteba A. M., Drummond W. H., Kosch P. C. (1990) Equine clinical neonatology, 1th ed., Lea \& Febiger, Philadelphia-London

Lassen E. D. (2007) Avaliação laboratorial das proteínas do plasma e do soro sanguíneo. In: Hematologia e Bioquímica Clínica Veterinária. $1^{a}$ ed. São Paulo: Roca, 376-390

Madej J. P., Nowacki W., Boratyński J., Borkowski J., Włodarczyk-Szydtowska A., Musia E. (2009) The relationship between concentrations of vitamin D-binding protein (DBP) in serum and colostrum of mares and in serum of their foals in the neonatal period. Pol. J. Vet. Sci. 12, 499-507

Magalhães F. J. R., Santiago T. A., Manso H. E. C. C. C., Abreu J. M. G., Ferreira L. M. C., Manso Filho H. C. (2017) Efeito da suplementação com concentrados ricos em óleo sobre biomarcadores metabólicos para cavalos. Medicina Veterinária (UFRPE), Recife, v. 11, n.2 (jan-mar), 114-121

Manso Filho H. C., Costa H. E. C., Santos F. L. (2000) Body growth of foals of three different breeds bred in Pernambuco. In: Congresso de Medicina Equina, AAVE, San Isidro, Argentina

McKeever J. M., McKeever K. H., Alberici J. M., Gordon M. E., Manso Filho H. C. (2006) Effect of omeprazole on markers of performance in gastric ulcer-free standardbred horses. Equine Vet. J. 36, 668-671; DOI 10.1111/i.2042-3306.2006.tb05624.x

Mélo S. K. M., Vaz S. G., Manso E. C. C., Martins I. D. S. L., Hunka M. M., Manso H. E. C. C. C, Manso Filho H. C. (2012) Influência da suplementação com concentrado extrusado, rico em óleo, nos parâmetros hematológicos, biométricos e biomarcadores na digestão de potros. Med. Vet. (UFRPE) 6, 41-45

Milinković-Tur S., Perić V., Stojević Z., Zdelar-Tuk M., Piršljin J. (2005) Concentrations of total proteins and albumins, and AST, ALT and GGT activities in the blood plasma of mares during pregnancy and early lactation. Vet. Archiv, 75, 195-202

National Research Council - NRC (2007) Nutrient requirements of horses. 6. ed. Rev. Washington, D. C.: National Academies, 360

Oldruitenborgh-Oosterbaan M. M. S., Annee M. P., Verdegaal E. J., Lemmens A. G., Beynen A. C. (2002) Exercise- and metabolism-associated blood variables in standardbreds fed either a low or a high-fat diet. Equine Vet. J. 34, 2932; DOI 10.1111/i.20423306.2002.tb05387.x

Piccione G., Assenza A., Fazio F., Bergerd D., Caola G. (2008) Daily rhythms of sérum vitamin D - Metabolites, Calcium and Phosphorus in Horses. Acta Vet. Brno; DOI 10.2754/ avb200877020151

Silva M. O. (2018) Valores hematológicos e bioquímicos em éguas Mangalarga Marchador no período de transição mantidas a pasto. In: Avaliação clínica e laboratorial em éguas Mangalarga Marchador durante o período de transição mantidas a pasto - Tese de Doutorado. Universidade Federal de Viçosa-MG, Brazil 